\title{
History \& Development of Human Rights in Indian
}

\author{
MS. NIDHI MADAN \\ PH.D ( Research Scholar)Dept. Of Education ,MDU, Rohtak.
}

\begin{abstract}
Human rights are those rights which are essential for the survival of humans and their life. Human rights are inculcated in the society right from the beginning of human civilization. Particularly the concept of "VasudhaibaKutumbakam" contains the spirit of human civilization. The "Rig Veda, the oldest document of the Indians declared all human beings are equal \& respect the dignity of human rights. The "Atharva Veda" advocated the same thing. In addition to this, ancient Indian stressed on the principle that one person's right is another person's duty. So, the need to feel the importance of human right has felt in the pre-independence era where the human fight for their rights with the national freedom movement launched by Mahatma Gandhi. In the Independent India, efforts have been made to define human rights education in the 1950's \& 1960's in formal school setting. But as time passes, the human rights perspectives have dominated the formulation of educational policies which is supported and recommended by major commissions and policy documents like University education commission, (RadhaKrishan Commission 1949). Secondary Education commission (Mudaliar Commission 1952) Education Commission ( Kothari Commission, 1964-1966), National Policies on Education (1968,1986), The Rammurthi Committee (1992), The Chavan Committee (1999), Programme of Action (1992) etc.Thus, the history of human rights which has its existence from the power of Rig Veda has developed as time passes to take a shape of human right as right to express, right to vote, right to education in respect of sex, caste or creed, right to information etc.
\end{abstract}

Keywords : Human Rights in ancient, medieval and modern times.

\section{INTRODUCTION}

The concept of human right began the start of the civilization on this earth. The human being in order to live happily, needs the rights to smooth his/her life. From the beginning of human history man struggled for his existence against nature and for liberty and freedom though these struggles for achieving basic freedom. This struggle paved the way to the concept of human rights. The most unique feature of human rights is that it is difficult to define but impossible to ignore. Human rights denotes all those rights which are inherent in our nature and without which humans can't live. These rights are indispensible for the human dignity which they can enjoy from birth to death.

\section{MEANING}

Human rights are commonly understood as "inalienable fundamental rights to which a person is inherently entitled simple because she or he is a human being".Human rights in the words of A.A. said, " are concerned with the dignity of the individual, the level of self-esteem that secures personal identity \& promote human community". According to Scott Davidson, "The concept of human rights is closely connected with the protection of individuals from the exercise of State, Government or authority in certain area of their lives, it is also directed towards creation of societal condition by the state in which individual are to develop their fullest potential". Thus, from the above cited definitions, it has been seen that human rights are the essential part for the every human in order to live his/her life to the fullest .

\section{The Indian Perspective on Human Rights}

\section{Human Rights in Ancient Times}

The concept of human right is not from western region. It is the crystallization of the values which are common for all the mankind. The United Declaration of Human Rights (1948) did not come from the leaved suddenly but its a milestone on the path on which the concept of human right is already travelling for centuries. In fact, the language of human right is the product of European countries but the concept of human rights is as old as the Indian culture. The humans expressed their concern towards human rights and fundamental freedom for all since the Vedic age. 
In ancient India, the trace of the concept of human rights can be paved back from the Vedas period of the fifteen century B.C. There are wide range of stories, pronouncements found which showed the way to the concept of human rights.In Vedas, human right is signified with the concept of equality. The Charter of equality of all as defined in the Vedas in the following words-No one is superior inferior allshould strive for the interest of alland should progress collectively.Kautilya beautifully sum up the concept of welfare state by saying that the happiness of the state lies in the happiness of his subjects.Under the period, the civil and legal rights first formulated by Manu but also added a number of economic rights. From the fact and stories, it is truly revealed that the society under vedic period was well stimulated and organized and committed towards human right. In fact, the importance of human rights were well supported by Jainism, Buddhism and other minority religious group. No discussion of human rights and their roots in the ancient period is left without giving the reference of Ashoka. Ashoka inscribes, "All men are my children and just desire for my children that they may enjoy every kind of prosperity and happiness with in this world and in the next, as also as I desire the same for all men". In fact, the king Ashoka worked day and night for the protection of human rights. It's unfortunate that the decline of human rights were witnessed with the decline of Mauryan Empire.

\section{Human Rights in Medieval Times}

As medieval period signifies the Muslim era in India. In the pre-mughal period the series of social, cultural, political and religious rights were existed but with the advent of Mughal, the Hindus were stressed badly. The concept of human rights got lost in the dark. But with the entry of Akbar's (1526-1605) period, once again great regard given to the social, religious and political rights. In his religious policy, Din-E-Ilahi (divinereligion), he tried to preach the idea of secularism and religious tolerance. Similarly, Various religious movements like Bhakti (Hindu) and Sufi (Islamic) made remarkable contribution to the emergence of human rights which at times suppressed by the other Mughal Empires like Aurangzeb, Babar, Humayun etc.

\section{Human Rights in Modern India}

This period starts from the advent of British empire. The process of Indian administration started by the Britishers with the introduction of Regulating Act of 1773. Under it, Indian were surpressed by the Britishers completely in context to social, economical, political \& religious rights in all the sphere of life. They were told that they did not deserve any rights. Basic rights such as rights to life \& livelihood, right to freedom, right to expression, right to equality, right to preach etc were denied to them.In such a atmosphere, the Indian leaders \& people feel that their rights had been lost in the hands of the colonial rule, so they thought of diverting back to fight for their rights. Perhaps the first explicit demand for fundamentals rights appeared in the Constitution of India Bill 1895. The Bill guaranted every Indian the right to expression, right to equality before law, right to property, right to personal liberty, right to education etc. A series of resolution were passed between 1917 \& 1919 for demanding civil rights \& equality. Another major development was drafted by "Mrs. Besant 's Common wealth of 1925." The Bill contained a list of seven fundamental rights -

(i) Liberty of person.

(ii) Freedom of conscience \& free profession \& practice of religion.

(iii) Free expression of opinion.

(iv) Free elementary education.

(v) Use of roads, public places, courts of justice \& the like.

(vi) Equality before the Law, irrespective of consideration of nationality.

(vii) Equality of the sexes.

The resolution was passed in 1927 which came into effect in May 1928, Motilal Nehru as its Chairman. It is known as Nehru Report which declared that its first concern of Indians was "to secure the fundamental rights that had been denied to them." Another achievement came in context to fundamental right was the Karachi resolution adopted by the congress session held in March 1931.The decade of 1940's was generally marked by the emergence of fundamental rights by the increased activities related to in by UN Assembly. The further stage of development of fundamental rights in Indian context was the "Sapra Committee Report" published at the end of 1945.So, after Independence, time to time various laws made, suggestions came from the various committees to enlarge the concept of fundamental rights by covering the entire human race.

\section{Human Rights Enshrined in Indian Constitution}

Human Rights in the Indian Constitution can be found in the Preamble of the Constitution of India. In addition to it, Part III- related to fundamental rights, Part IV-Directive Principles which together form the core of the

\section{Constitution.}

A. PREAMBLE:- It is the sort of introductory statement that gives the guiding purpose \& principle of the document.Preamble stated :WE, THE PEOPLE OF INDIA, having solemnly resolved to constitute India into a 
SOVEREIGN, SOCIALIST, SECULAR, DEMOCRATIC, REPUBLIC \& to secure to all its citizens JUSTICE, social, economic \& politicalLIBERTY of thought, expression, belief, faith \& worship.EQUALITY of status \& of opportunity and to promote among them allFRATERNITY assuring the dignity of the individual \& the unity \& integrity of the Nation.

\section{IN OUR CONSTITUENT ASSEMBLY THIS TWENTY-SIXTH DAY OF NOVEMBER 1949, DO HEREBY ADOPT, ENACT AND GIVE TO OURSELVES THIS CONSTITUTION.}

\section{B. THE FUNDAMENTAL RIGHTS}

The rights that are basic for the freedom of humans so that they can live \& enjoy as it for the proper \& harmonious development of their personality are known as fundamental rights.

These rights are applied universally irrespective of caste, race, creed, religion, color or gender. They are enforced by the courts subject to certain articles. There are six fundamentals rights which are as follows:

\section{RIGHT TO EQUALITY}

\begin{tabular}{|l|l|l|}
\hline $\begin{array}{l}\text { S. } \\
\text { No. }\end{array}$ & Name of the Rights & Indian Constitution \\
\hline 1. & Equality before Law & Article 14 \\
\hline 2. & Social Equality \& equal access to public areas. & Article 15 \\
\hline 3. & Equality in matters of public employment & Article 16 \\
\hline 4. & Abolition of untouchability & Article 17 \\
\hline 5. & Abolition of titles & Article 18 \\
\hline
\end{tabular}

\section{RIGHT TO FREEDOM}

These rights are considered vital by the framers. It contains Articles 19 to Article 22 which are as follows:

\begin{tabular}{|l|l|l|}
\hline S. No. & Name of the Rights & Indian Constitution \\
\hline 1. & $\begin{array}{l}\text { (i) Freedom of speech \& expression. } \\
\text { (ii) Freedom to assemble peacefully without arms. } \\
\text { (iii) Freedom to form associations or unions. } \\
\text { (iv) Freedom to move freely throughout the territory of India though } \\
\text { reasonable restrictions can be imposed on this right in the interest of the } \\
\text { general public. } \\
\text { (v) Freedom to reside \& settle in any part of the territory of India. } \\
\text { (vi) Freedom to practice any profession or to carry on any occupation, trade or } \\
\text { business. }\end{array}$ & $\begin{array}{l}\text { Article } \\
\text { (i) No one can be awarded punishment which is more than what the law } \\
\text { prescribed. } \\
\text { (ii) No one can be convicted twice for the same offence. } \\
\text { (iii) Protection of life and personal liberty. }\end{array}$ \\
\hline 3. & $\begin{array}{l}\text { (i)No citizen can be denied his life and liberty expect by law. } \\
\text { (ii) Every child has the right to get free and compulsory education. }\end{array}$ & Article 21 \\
\hline 4. & $\begin{array}{l}\text { (i) No one can be arrested without being told the grounds for his arrest. } \\
\text { (ii) Arrested citizen has to be brought before the nearest magistrate within 24 } 21 \mathrm{~A} \\
\text { hours. }\end{array}$ & Article 22 \\
\hline
\end{tabular}

VI. RIGHT AGAINST EXPLOITATION

Under it, Article $23 \& 24$ has been given the provisions which are as follows:

\begin{tabular}{|l|l|l|}
\hline S. No. & Name of the Rights & Indian Constitution \\
\hline 1. & $\begin{array}{l}\text { Abolition of trafficking in human beings and begar (forced } \\
\text { labor) }\end{array}$ & Article 23 \\
\hline 2. & $\begin{array}{l}\text { Abolition of employment of children below the age of } \\
\text { 14years in dangerous jobs like factories, mines etc. }\end{array}$ & Article 24 \\
\hline
\end{tabular}

VII. RIGHT TO FREEDOM OF RELIGION

Under it Article 25, 26, 27 and 28 are covered which are described as under:

\begin{tabular}{|l|l|l|}
\hline S. No. & Name of the Rights & Indian Constitution \\
\hline 1. & Religious freedom to all citizens of India & Article 25 \\
\hline 2. & $\begin{array}{l}\text { Religious communities can setup charitable institution of } \\
\text { their own. }\end{array}$ & Article 26 \\
\hline 3. & $\begin{array}{l}\text { No person shall be compressed to pay taxes for the } \\
\text { promotion of a particular religion. }\end{array}$ & Article 27 \\
\hline
\end{tabular}




\begin{tabular}{|c|c|c|}
\hline 4. & $\begin{array}{l}\text { State run institutions cannot impart education that is pro } \\
\text { religious. }\end{array}$ & Article 28 \\
\hline \multicolumn{3}{|c|}{ CULTURED \& EDUCATIONAL RIGHTS } \\
\hline S. No. & Name of the Rights & Indian Constitution \\
\hline 1. & $\begin{array}{l}\text { No citizen can be discriminated against for admission in state } \\
\text { or state aided institutions. }\end{array}$ & Article 29 \\
\hline 2. & $\begin{array}{l}\text { All minorities, religions or linguistic can set up their own } \\
\text { educational; institutions to preserve \& develop their own } \\
\text { culture. }\end{array}$ & Article 30 \\
\hline
\end{tabular}

\section{RIGHT TO CONSTITUTIONAL REMEDIES}

This right covered under Article 32.

\begin{tabular}{|l|l|l|}
\hline S. No. & Name of the Rights & Indian Constitution \\
\hline 1. & $\begin{array}{l}\text { It empowers the citizens to move a court of law in case of any } \\
\text { denial of the fundamentals rights. }\end{array}$ & Article 32 \\
\hline
\end{tabular}

\section{DIRECTIVE PRINCIPLES OF STATE POLICY}

These principles are embodied in Part-IV of the Constitution. In it the directions are given to the states for the establishment of social \& economic democracy as proposed by the Preamble. The state is expected to keep these principles in mind while framing laws and policies. Under it, following articles are included:

\begin{tabular}{|c|c|c|}
\hline S. No. & Name of the Principle & Indian Constitution \\
\hline 1. & $\begin{array}{l}\text { It declare that the principles are fundamental to the governance of the } \\
\text { country \& impose an obligation on the state to apply them in matters of } \\
\text { legislation. }\end{array}$ & Article 37 \\
\hline 2. & $\begin{array}{l}\text { It emphasize the positive duty of the state to promote the welfare of the } \\
\text { people, to fight against equality and to ensure individual dignity. }\end{array}$ & Article 38 \\
\hline 3. & $\begin{array}{l}\text { (i) Providing adequate means of livelihood of all citizens. } \\
\text { (ii) To provide free legal aid to ensure equal justice to all. }\end{array}$ & $\begin{array}{l}\text { Article } 39 \\
\text { Article } 39 \text { A }\end{array}$ \\
\hline 4. & $\begin{array}{l}\text { State should work for the organization of village panchayats \& help them } \\
\text { to function as units of Self-government. }\end{array}$ & Article 40 \\
\hline 5. & $\begin{array}{l}\text { State should provide right to work, to education and to public assistance in } \\
\text { cases of unemployment, old age, sickness \& disablement within the limits } \\
\text { of economic capacity. }\end{array}$ & Article 41 \\
\hline 6. & $\begin{array}{l}\text { State should provide for just and humane conditions of work and } \\
\text { maternity relief. }\end{array}$ & Article 42 \\
\hline 7. & $\begin{array}{l}\text { (i) State should ensure living wage \& proper conditions for workers, with } \\
\text { full enjoyment of leisure and social and cultural activities. } \\
\text { (ii) State should take steps to promote their participation in management } \\
\text { of industrial undertakings. }\end{array}$ & $\begin{array}{l}\text { Article } 43 \\
\text { Article } 43 \mathrm{~A}\end{array}$ \\
\hline 8. & State shall endeavor to secure a uniform civil code for all citizens. & Article 44 \\
\hline 9. & $\begin{array}{l}\text { State should provide free and compulsory education to all children till } \\
\text { they attain the age of } 14 \text { years. }\end{array}$ & Article 45 \\
\hline 10. & $\begin{array}{l}\text { State should to work for the economic and educational upliftment of caste, } \\
\text { scheduled and other weaker sections of the society. }\end{array}$ & Article 46 \\
\hline 11. & $\begin{array}{l}\text { State shall commit to raise the level of nutrition and the standard of living } \\
\text { and to improve public health. }\end{array}$ & Article 47 \\
\hline 12. & $\begin{array}{l}\text { (i) State should organize agriculture and animal husbandry on modern and } \\
\text { scientific lines. } \\
\text { (ii) State should protect and improve the environment and safeguard the } \\
\text { forests and wild life of the country. }\end{array}$ & $\begin{array}{l}\text { Article } 48 \\
\text { Article } 48 \mathrm{~A}\end{array}$ \\
\hline 13. & $\begin{array}{l}\text { Obligation of the state to protect the places, monuments and objects of } \\
\text { historic and artistic interest and national importance against destruction } \\
\text { and damage. }\end{array}$ & Article 49 \\
\hline 14. & State should do separation of judiciary from executive in public services. & Article 50 \\
\hline 15. & $\begin{array}{l}\text { State shall strive for the promotion and maintenance of internationally } \\
\text { peace and security. }\end{array}$ & Article 51 \\
\hline
\end{tabular}

\section{Fundamental Duties.}

According to Eighty Six constitution amendment Act, 2002, there are now 11 fundamental duties of the citizen of India that are as follow:-(i) Respect the National Flag and the National Anthem.(ii) To cherish and follow the noble ideals which inspired our national struggle for freedom.(iii) To uphold and protect the sovereignty, unity and integrity of India.

(iv) To defend the country and render national service when called upon to do so; 
(v) To promote harmony and the spirit of common brotherhood amongst all people of India;

(vi) To value and preserve the rich heritage of our composite culture;

(vii) To protect and improve the natural environment;

(viii) To develop the scientific temper, humanism and the spirit of inquiry and reform;

(ix) To safeguard public property and to abjure violence;

(x) To strive towards excellence in all spheres of individual and collective activity;

(xi) To provide opportunities for education by the parent, the guardian, to his child.

\section{Policy Pronouncements and human right education}

The report given by various Indian Education Commissions and education policy. Statements have stressed on the importance of human rights and its development in the educational system. Major Commissions and policy documents like University Education Commission (1949), Secondary Education Commission (1952), Education Commission (1964-66), National Policies on Education (NPE - 1968,86), The Ramamurthi Committee (1992), the Chavan Committee (1992) were established to develop the concept of human rights in education as Value-Oriented educational system.

\section{Chronology of events/Indian Laws regarding human rights in India.}

Following is a list of some of the important national statutes which have a bearing on the promotion/ protection of human Rights in India.

1829 - The practice of sati was formally abolished.

1923 - Workmen's Compensation Act.

1926 - Trade Unions Act.

1929 - Child Marriage Restraint Act.

1933 - Children ( Pledging of Labor) Act.

1936 - Payment of Wages Act.

1946 - Industrial Employment Standing Orders Act.

1947 - Industrial Disputes Act.

1948 - Minimum Wages Act.

1950 - Caste Disabilities Removal Act.

1955 - Protection of Civil Rights Act.

1956 - Immoral Traffic Act.

1961 - Maternity Benefit Act.

1976 - Equal Remuneration Act.

1986 - Environmental Protection Act.

1986 - Juvenile Justice Act.

1987 - Commission Of Sati ( prevention) Act.

1990 - National Commission for Women Act.

1993 - Establishment of Human Rights Commission.

2005 - Right to Information Act passed.

2010 - The Right of Children to Free and Compulsory Education Act came into force etc.

\section{CONCLUSION}

From the above details, it has been concluded than the history of the concept of human rights is from the advent of human culture which grow in the Vedic period, passed through the medieval and modern times and reached its due importance with the framing of the constitution of India in which due importance has been given to human rights in context to fundamental rights, directive principles and fundamental duties.

\section{REFERENCES}

[1] Arun Raj, National Rights Commission of India, formation, functioning and fututr prospects, vol-1. Khana, New Delhi,2005, p.37

[2] Durga Das Basu, Human Rights in Constitutional law. Prentic Hall of india. New Delhi,1994,p.540

[3] Malkit Singh, "Thinking of Human Rights in Colonial India." Research Journal Social Science. Vol15 no.2.,2007, p.84

[4] J.C.Johari, Human Rights and New World Order Towards Perfection of the Democratic way of life,Anmol. New Delhi,1996,p.2

[5] Arun Ray,n.1.pp.45-46

[6] Arun Ray, n.1, p.38

[7] Ibid.,pp.38-39 
[8] M.Sundara Raj," Awakening of Human Rights”,C.J.Nirmal(ed.), Human Rights in India, Historical, Social and Political Perspective. Oxford University press, New Delhi,2006,p.3

[9] M.Sundara Raj,n.8.p.4.

[10] Ibid.,p.447.

[11] Arun Raj,n.i,pp.42-43

[12] Vijaya KumarV.," The working of the National Human Rights Commission ,A Perspective." C.J.Nirmal(ed.)Human Rights in India, Historical, Social and Political Perspective. Oxford University press. New Delhi,2000,p.274.

[13] Arun Ray,n.1.p.43.

[14] Ibid,p.83,94-96.

[15] Human Rights A Source Book- NCERT

[16] Indian Constitution

[17] Wikipedia

[18] NHRC. 